\title{
Commercial Humates in Agriculture: Real Substance or Smoke and Mirrors?
}

\author{
Graham Lyons ${ }^{1}$ and Yusuf Genc ${ }^{1,2, *}$ \\ 1 School of Agriculture, Food and Wine, University of Adelaide, Waite Campus, Glen Osmond, SA 5064, \\ Australia; graham.lyons@adelaide.edu.au \\ 2 South Australian Research and Development Institute, Plant Genomics Centre, Waite Campus, \\ Glen Osmond, SA 5064, Australia \\ * Correspondence: yusuf.genc@adelaide.edu.au; Tel.: +61-88-303-9425
}

Academic Editor: Mike McLaughlin

Received: 27 September 2016; Accepted: 26 October 2016; Published: 28 October 2016

\begin{abstract}
Soil humic substances (HS) are known to be beneficial for soils and plants, and most published studies of HS and humates, usually conducted under controlled conditions, show benefits. However, the value of commercial humate application in the field is less certain. This review attempts to answer the question: How effective are commercial humates in the field? Commercial humates, especially K humate, are used widely in agriculture today as "soil conditioners". A wide range of benefits is claimed, including growth of beneficial soil microbes; deactivation of toxic metals; improvements in soil structure including water retention capacity, enhanced nutrient and micronutrient uptake and photosynthesis; resistance to abiotic stress, including salinity; and increased growth, yield and product quality. Despite this, there is a surprising lack of solid evidence for their on-farm effectiveness and findings are often inconsistent. The industry relies largely on anecdotal case studies to promote humates, which are often applied at unrealistically low levels. It is recommended that products should be well characterised, physically and chemically, and that careful field studies be conducted on foliar humate application and pelletised humates at realistic rates, targeted to the seedling rhizosphere, for a variety of crops in a range of soils, including low $\mathrm{C}$ sandy and saline soils.
\end{abstract}

Keywords: commercial humates; potassium humate; humic substances; abiotic stress; plant growth; yield; lignite; agriculture

\section{Introduction}

"Few agricultural products have been subject to more confusion and conflicting information than humic-type additives" [1]. With this unpromising but valid observation, we introduce our brief review in the hope that, if not providing notable clarification, we will at least not muddy the waters further.

Waksman [2] reviewed publications on the origin, composition and importance of humic materials. Humus is Latin for soil, and humic substances (HS) are natural organic compounds which are sourced from plants, peat, soil and coals such as lignite and leonardite. Note that leonardite actually refers to a particular geological deposit of oxidised lignite in North Dakota, but is often misapplied to lignitic deposits found elsewhere [3]. HS have been the subject of numerous studies due to their mitigating effects on contaminant toxicity to both biota and abiotic stress conditions (high/low temperature, high/low pH, salinity) [4]. Humates are salts of humic acids, the most active component of HS, which are more soluble and thus more reactive in soil [5].

It has been over 50 years since the publication of Burdick's article on commercial humates for agriculture. The author's sanguine review, supported by Mayhew [6] and Ouni et al. [7], documented numerous benefits of humate application to plants, including increases in soil water retention, growth of beneficial soil micro-organisms (especially if exposed to contaminant toxicity), root respiration, 
enzyme activity, root growth, and plant yield. Humates were described as "nature's soil conditioners par excellence" and the author expressed surprise, given the apparent great market potential, that the agricultural and fertiliser industries had not developed humates commercially [5].

Burdick would be doubtless impressed by the popularity of commercial humates today [8]. More than 200 humic products are being made and marketed by Australian companies along with others from overseas suppliers [9]. It is estimated that around 10,000 tonnes of $\mathrm{K}$ humate costing $\$ 1500-2200 / \mathrm{t}$ are applied in Australia per year at $5-10 \mathrm{~kg} / \mathrm{ha}$ and $25 \mathrm{~kg} / \mathrm{ha}$ for saline soils, mostly "down the tube" with fertiliser [10] but also in liquid form in irrigation systems [11]. Given their widespread use, it is timely to review the current status and future opportunities for the research and application of commercial humates in agriculture. It is not our purpose to review studies of HS per se, but rather to find links between the findings of controlled environment studies and the effects of humates in the field. In particular, this review will attempt to answer the question: How effective are commercial humates in the field?

\section{Literature Review}

A vast amount of literature exists on the effects of HS on soil micro-organisms, plant physiology and plant growth, and important reviews include those of Canellas and Olivares [12] and Nardi et al. [13], the latter focussing on the biostimulant role of HS and protein hydrolysed-based products. The authors noted that the biostimulatory activity of HS was usually due to hormone-like activity, which may be due to auxins, which were analysed in the HS. Roots appear to be affected most by the growth-promoting effects of HS, with increases in size, branching and/or greater density of root hairs with larger surface area [14]. Nardi et al. [15] showed that HS affected the enzyme activities related to glycolysis and the tricarboxylic acid cycle in different ways, depending on humic molecular size, molecular characteristics and concentration.

HS comprise complicated organic mixtures which are linked together in a random manner, resulting in extraordinarily complex materials $[1,6,9,16]$. They contain an abundance of carboxyl groups and weakly acidic phenolic groups and can bind to soil mineral surfaces. Most commercially available HS are extracted from soft brown coal-like deposits with an alkali solution. Given the wide range of extraction methods and processes used to produce commercial products, together with a lack of detailed knowledge of many HS [17], it is often difficult to compare materials $[1,9,18]$. Even commercial humates with the same origin, produced by the same company can differ widely in composition [19]. Due to the numerous recommendations for use, it is difficult to specify a strategy applicable to a range of crops, soils and growing conditions [1].

There is a range of humates available commercially for use in agriculture, e.g., $\mathrm{K}, \mathrm{Ca}, \mathrm{B}, \mathrm{Na}$, usually used for the purposes of (1) increasing production in soils with heavy metal contamination, salinity, sodicity, extreme $\mathrm{pH}$, low water content, adverse temperature and low organic matter, and (2) increasing the efficiency of inorganic fertilisers [4,9,20]. In accord with Burdick's 1965 review [5], most published articles on humates report positive results [1], which include increased plant growth and yield [18,21-28] and/or reduced yield depression under abiotic stress, including salinity [4,29-35].

Although some researchers consider that HS exert multiple direct effects on plant growth in addition to "hormone-like activity", especially under abiotic stress [7,28,36], others regard the effects of humates (in the absence of plant hormones) on plant growth as being indirect: they can alter soil properties by increasing friability, buffering $\mathrm{pH}$, increasing water retention, complexing trace metals and increasing their availability [37] along with that of macronutrients. For example, Fe-humate is an effective Fe source for citrus trees planted in alkaline soils, which increased tree growth and fruit production of orange and grapefruit [38]. Furthermore, organic substances have been demonstrated to enhance the solubility of soil $\mathrm{P}$ through complexation of $\mathrm{Fe}$ and $\mathrm{Al}$ in acid soils and $\mathrm{Ca}$ in calcareous soils. However, there is currently not enough research to explain possible mechanisms and accurately predict when humic materials might prove beneficial $[1,9,20]$. Moreover, benefits appear to be greater in hydroponic and sand culture studies under controlled conditions $[3,9,20,39]$. 
Other studies have found no effect [33,34,40,41] or even growth reduction [42,43] from humate application. A study of maize and humic acid reported a "root fouling effect" resulting from humic acid accumulation at root cell walls that was associated with reduced shoot growth, transpiration and resistance to water stress [43]. Indeed, studies have reported all outcomes in trials: positive, negative and nil effects [8].

\subsection{Inconsistent Results}

There are few rigorous field studies to show benefit from on-farm humate/humic acid application, and findings are variable and inconsistent $[1,3,9,20,39,44]$. For example, Little et al. [44] found mostly positive shoot and root growth responses with humic acid addition to two different soils for lucerne but not for ryegrass; microbial biomass increased for ryegrass, but not for lucerne on the high $\mathrm{pH}$ soil, but was not associated with plant yield. The Masters thesis of Van Tonder in South Africa also illustrates the inconsistency of humate findings. Three experiments were conducted to examine the effect of $\mathrm{K}$ humate on soil properties and wheat response. In a growth room trial chemical soil properties showed no response after five months, and in glasshouse and field trials "virtually no significant influences" were found with the K humate application rate and soil texture interaction on the measured parameters, growth and yield, using five humate applications $(0,1.5,3,5$ and $6 \mathrm{~L} / \mathrm{ha})$ and three clay levels $(8 \%, 22 \%$ and $37 \%)$. Indeed, at tillering, the greatest dry matter production was obtained with the control treatment, whereas the K humate treatments produced lower yields [42].

\subsection{Exaggerated Claims}

Although addition of oxidised lignite to soils with low humic content may help to increase aggregate stability and available water capacity, there is limited evidence for the specific effects of humates on plant drought tolerance, water use efficiency and enhancement of soil microbial activity $[3,9,20]$. Moreover, promoters of commercial humates often suggest that they have biological and chemical properties similar to those of humus in soil. However, the composition and properties are substantially different, as these products are essentially free of such biologically important compounds as proteins and polysaccharides. Humic acids sourced from compost, mulch, peat and lignite coal have been shown to have similar characteristics to those in soils [17,37], although lignite humic acids have a higher $\mathrm{C}$ content, indicating that they will be less soluble [42].

Incisive publications on this subject include those by Mikkelsen [1], Karr [3], Billingham [9,20], Susic [37] and Little et al. [44]. These authors, along with a USDA [39] report, all conclude that despite most published studies showing benefits (including increased growth) of HS, including humates, to plants, there is little evidence for their effectiveness in the field. Products are usually aligned with naturally occurring HS. Billingham [9] observes that "There is a remarkable similarity between the claims made about humic products and the well-established properties of HS. Treating an organic material with alkali and acid may produce something that looks like a humate, but it may not behave like one." Reports by commercial enterprises on the beneficial effects of oxidised lignite "are often a series of side-by-side comparisons without statistical analyses, or are performed at a single location or over a single year", hence limiting inference and generalisation [3].

A lack of solid evidence has not inhibited enthusiastic promotion of humate products by some businesses, and "unfortunately, many of the small (fertiliser) companies make unsubstantiated and often ridiculous claims about humic (and fulvic) acids, which gives these products a poor image when the supposed results do not eventuate" [45]. Businesses have "a vested interest in demonstrating positive outcomes from their experiments ... the industry relies largely on anecdotal case studies to promote these products to farmers and claims are often exaggerated" [3]. For example: "Humates are now recognised as the single most productive input in sustainable agriculture" [46]. A survey of 10 commercial humic products found that humic acid content varied from advertised levels in some cases by more than $800 \%$ [47]. Vendors know they will not be prosecuted, regardless of their claims, and researchers have called for mandatory quality control by regulatory bodies [8]. 


\subsection{Are Recommended Application Rates too Low for Effect?}

Many studies show little or no benefit when humates are applied to the field at recommended rates (for K humate commonly 5-10 kg/ha), which are likely to be too low to be effective $[1,3,9,20,44,47-51]$. It is unlikely that, at these rates, there are sufficient quantities of the active components to produce the claimed benefits [52]. A more cynical view is that "(Vendors recommend low rates) to enjoy huge mark ups on their product, but still keep the product affordably priced at the usage rates recommended. For example, one vendor of a dry, water soluble product recommends a rate of 2 oz per acre, and sells the product to retailers at $\$ 16,000$ per ton!" [3]. The relative costs of these materials should be compared against other strategies to improve active organic matter or increase micronutrient availability $[9,39]$.

Little [53] found that application of soluble humate granules at rates up to $20 \mathrm{~kg} / \mathrm{ha}$ provided shoot and root growth in lucerne and ryegrass, with maximum benefit gained at $20 \mathrm{~kg} / \mathrm{ha}$, five times the manufacturer's recommended rate. There was no further benefit at rates above this. However, in a study of cotton and ammonium humate, the high rate of $400 \mathrm{~kg} / \mathrm{ha}$ of humate produced the highest growth and uptake of $\mathrm{P}$ [54]. At this rate, it may have been the nitrogen in the compound that produced the positive result. Indeed, it could be argued that any benefits resulting from the use of commercial humates, especially on poor soils, could be due to nitrogen, phosphorus or other mineral components, rather than to humic acid itself. However, at the low rates discussed above, any benefits are unlikely.

A benefit often claimed by retailers is that HS can provide a $C$ source for soil microorganisms. This mechanism does not appear to be likely, since a typical application will supply only $3-15 \mathrm{~kg}$ $\mathrm{C} /$ ha (1). Australian agricultural soils contain an estimated 13-21 tonnes/ha of natural HS, which accounts for $50 \%-80 \%$ of the organic carbon in these soils [9]. Moreover, around 4 tonnes $\mathrm{C} / \mathrm{ha}$ is returned in the residue of a typical corn crop. Large amounts of organic matter addition are required to make significant changes to soil organic mattercontent, and this usually takes a long time [1]. Edmeades [46] is similarly sceptical. However, it may be feasible to produce benefits in localised soil zones, such as the seedbed or in a fertiliser band [1]. Since HS are formed in senescent plant matter, it is important that residues from harvested crops are returned to the soil; therefore stubble should not be burnt: leaving it to break down will eventually increase soil HS. South Australian grain growers are increasing yields on saline soils by spreading chaff and straw on affected areas [55]. Humic acid-rich-materials (including composts, mulch, peat, lignite coals) are better than commercial $\mathrm{K}$ humate products, which are easily leached by rainfall and irrigation: "Commercial soluble $\mathrm{K}$ humate products provide little long-term benefit and are relatively expensive, so they are not a good proposition" [37].

\section{Future Research}

The issues of inconsistent results, exaggerated claims and unrealistically low application rates highlight the clear need for effective quality control $[8,9,20,47]$, which would be based on in-depth characterisation, physical and chemical (i.e., elemental and spectroscopic analysis [17], of commercial humates. For example, the effective application rate is influenced by the nature of the humate, including the type of organic matter from which it is derived and the extractant used. Each fraction comprises a series of molecules of different sizes. Nuclear magnetic resonance (NMR) and infrared (IR) imaging can be used as complementary methods to characterise HS. Helal et al. [56] showed that simple, inexpensive methods such as elemental analysis and potentiometric titration provided good agreement with the more powerful and expensive NMR and IR. Studies that include in-depth humate/humic acid characterisation include Ertani et al. [26], Mora et al. [28] and Schiavon et al. [36].

It is clear that much further research, in particular well targeted field trials, is needed in order to elucidate mechanisms of action of commercial humates at this level. This could include, for example, evaluation of pelletised humates applied with fertiliser or as pellets containing both fertiliser and humate "in the row" in low $\mathrm{C}$, high $\mathrm{pH}$, saline-sodic soils $[26,29,32,35]$. In addition, more information is needed on interactions between HS and plants, and their impact on nutrient cycling. Field studies 
that include a wide range of application rates, including some rates well above those commonly recommended, are needed to match HS with specific soils and crops [44]. In the meantime, farmers can keep careful records and conduct their own field trials to determine product effectiveness [1].

Using wheat treated with foliar fulvic acid, Xudan [57] obtained spectacular results, including normalising of yield under drought conditions to that of the irrigated control, by reducing stomatal conductance, increasing chlorophyll and increasing P uptake by roots. Other positive results from the foliar application of HS include a $22 \%$ increase in potato tuber yield associated with application of just $0.45 \mathrm{~kg}$ Na humate/ha [58] and increased potato yield from foliar K humate [59]. These findings, coupled with the relatively high cost of humates, suggest that foliar application may be more economical (due to the small quantities needed) and more effective than soil application [52]. Conversely, in another study, HS applied to soil increased wheat biomass, while foliar HS did not [25], providing another example of the inconsistent actions of humates on plants.

\section{Conclusions}

Burdick [5] would not be surprised at the widespread commercial use of humates in agriculture today; but what may surprise him is the lack of evidence for their on-farm effectiveness. Despite most published studies under controlled conditions showing benefits, including increased growth from HS addition, there are few rigorous studies which have investigated the effectiveness of commercial humates in the field, and findings are highly variable. The industry relies largely on anecdotal case studies to promote such products to farmers. To reiterate, it is concluded that the smoke and mirrors description of commercial humates is currently more appropriate than real substance.

In order to try to determine whether there is a genuine role for commercial humates in agriculture it is recommended that careful field studies be conducted on foliar humate application and pelletised humates at application rates sufficient to have an effect, targeted to the seedling rhizosphere for a variety of crops in low $\mathrm{C}$ sandy and saline soils.

Acknowledgments: The South Australian Grain Industry Trust Fund (SAGIT) for funding the project Identification of sodicity-tolerant oat varieties, which included writing this review.

Author Contributions: Yusuf Genc suggested that a review of commercial humate use was timely, and identified relevant literature. Graham Lyons wrote the first draft, and Yusuf Genc and Graham Lyons revised and improved the manuscript.

Conflicts of Interest: The authors declare no conflict of interest.

\section{References}

1. Mikkelsen, R.L. Humic materials for agriculture. Better Crop. 2005, 89, 6-10.

2. Waksman, S.A. Humus, Origin, Chemical Composition, and Importance in Nature, 2nd ed.; Wilkins: Baltimore, MD, USA, 1938.

3. Karr, M. Oxidized Lignites and Extracts from Oxidized Lignites in Agriculture. Available online: http: / / humates.com/HumatesinAgriculture-Karr.pdf (accessed on 27 September 2016).

4. Kulikova, N.A.; Stepanova, E.V.; Koroleva, O.V. Mitigating activity of humic substances: Direct influence on biota. In Use of Humic Substances to Remediate Polluted Environments: From Theory to Practice; Springer: Dordrecht, The Netherlands, 2005; pp. 285-309.

5. Burdick, E.M. Commercial humates for agriculture and the fertilizer industry. Econ. Bot. 1965, 19, $152-156$. [CrossRef]

6. Mayhew, L. Humic substances in biological agriculture. Acres 2004, 34, 1-2.

7. Ouni, Y.; Ghnaya, T.; Montemurro, F.; Abdelly, C.; Lakhdar, A. The role of humic substances in mitigating the harmful effects of soil salinity and improve plant productivity. Int. J. Plant Prod. 2014, 8, 353-374.

8. Lodhi, A.; Tahir, S.; Iqbal, Z.; Mahmood, A.; Akhtar, M.; Qureshi, T.M.; Yaqub, M.; Naeem, A. Characterization of commercial humic acid samples and their impact on growth of fungi and plants. Soil Environ. 2013, $32,63-70$. 
9. Billingham, K. Humic products-potential or presumption for agriculture? Can humic products improve my soil? In Proceedings of the 27th Annual Conference of the Grassland Society of NSW Inc., Orange, NSW, Australia, 24-26 July 2012; Harris, C., Lodge, G., Waters, C., Eds.; Grassland Society of NSW Inc.: Wagga Wagga, Australia, 2012; pp. 43-50.

10. VanderSluys, A. (Adelaide, South Australia). Personal communication, 2016.

11. Australian Humates. Available online: http://www.australianhumates.com.au (accessed on 5 September 2016).

12. Canellas, L.P.; Olivares, F.L.; Okorokova-Facanha, A.L.; Facanha, A.R. Humic acids isolated from earthworm compost enhance root elongation, lateral root emergence, and plasma membrane $\mathrm{H}^{+}$-ATPase activity in maize roots. Plant Phys. 2002, 130, 1951-1957. [CrossRef] [PubMed]

13. Nardi, S.; Pizzeghello, D.; Schiavon, M.; Ertani, A. Plant biostimulants: Physiological responses induced by protein hydrolyzed-based products and humic substances in plant metabolism. Sci. Agric. 2016, 73, 18-23. [CrossRef]

14. Canellas, L.P.; Olivares, F.L. Physiological responses to humic substances as plant growth promoter. Chem. Biol. Technol. Agric. 2014, 1, 3. [CrossRef]

15. Nardi, S.; Muscolo, A.; Vaccaro, S.; Baiano, S.; Spaccini, R.; Piccolo, A. Relationship between molecular characteristics of soil humic fractions and glycolytic pathway and krebs cycle in maize seedlings. Soil Biol. Biochem. 2007, 39, 3138-3146. [CrossRef]

16. Garcia, A.C.; de Souza, L.G.A.; Pereira, M.G.; Castro, R.N.; Garcia-Mina, J.M.; Zonta, E.; Lisboa, F.J.G.; Berbera, R.L.L. Structure-property-function relationship in humic substances to explain the biological activity in plants. Sci. Rep. 2016, 6, 20798. [CrossRef] [PubMed]

17. Nardi, S.; Pizzeghello, D.; Muscolo, A.; Vianello, A. Physiological effects of humic substances on higher plants. Soil Biol. Biochem. 2002, 34, 1527-1536. [CrossRef]

18. Lobartini, J.C.; Tan, K.H.; Rema, J.A.; Gingle, A.R.; Pape, C.; Himmelsbach, D.S. The geochemical nature and agricultural importance of commercial humic matter. Sci. Total Environ. 1992, 113, 1-15. [CrossRef]

19. Iakimenko, O.S. Commercial humates from coal and their influence on soil properties and initial plant development. In Use of Humic Substances to Remediate Polluted Environments: From Theory to Practice; Springer: Dordrecht, The Netherlands, 2005; pp. 365-378.

20. Billingham, K. Humic Products-Potential or Presumption for Agriculture; New South Wales Department of Primary Industries: Orange, NSW, Australia, 2012.

21. Gaur, A.C.; Bhardwaj, K.K.R. Influence of sodium humate on the crop plants inoculated with bacteria of agricultural importance. Plant Soil 1971, 35, 613-621. [CrossRef]

22. Adani, F.; Genevini, P.; Zaccheo, P.; Zocchi, G. The effect of commercial humic acid on tomato plant growth and mineral nutrition. J. Plant Nutr. 1998, 21, 561-575. [CrossRef]

23. Sharif, M.; Khattak, R.A.; Sarir, M.S. Effect of different levels of lignitic coal derived humic acid on growth of maize plants. Commun. Soil Sci. Plant Anal. 2002, 33, 3567-3580. [CrossRef]

24. Ece, A.; Saltali, K.; Eryigit, N.; Uysal, F. The effects of leonardite applications on climbing bean (Phaseolus vulgaris L.) yield and some soil properties. J. Agron. 2007, 6, 480-483.

25. Katkat, A.V.; Celik, H.; Turan, M.A.; Asik, B.B. Effects of soil and foliar applications of humic substances on dry weight and mineral nutrients uptake of wheat under calcareous soil conditions. Aust. J. Basic Appl. Sci. 2009, 3, 1266-1273.

26. Ertani, A.; Francioso, O.; Tugnoli, V.; Righi, V.; Nardi, S. Effect of commercial lignosulfonate-humate on Zea mays L. metabolism. J. Agric. Food Chem. 2011, 59, 11940-11948. [CrossRef] [PubMed]

27. Tahir, M.M.; Khurshid, M.; Khan, M.Z.; Abbasi, M.K.; Kazmi, M.H. Lignite-derived humic acid effect on growth of wheat plants in different soils. Pedosphere 2011, 21, 124-131. [CrossRef]

28. Mora, V.; Bacaicoa, E.; Baigorri, R.; Zamarreno, A.M.; Garcia-Mena, J.M. NO and IAA key regulators in the shoot growth promoting ction of humic acid in Cucumis sativus L. J. Plant Growth Regul. 2014, 33, 430-439. [CrossRef]

29. Lee, Y.S.; Bartlett, R.J. Stimulation of plant growth by humic substances. Soil Sci. Soc. Am. J. 1976, 40, 876-879. [CrossRef]

30. Fecenko, J.; Lozek, O.; Mazur, B.; Mazur, K. Resorption of macronutrients and cadmium in dependence on application of sodium humate. Rostl. Vyr. 1997, 43, 37-42. 
31. Asik, B.B.; Turan, M.A.; Celik, H.; Katkat, A.V. Effects of humic substances on plant growth and mineral nutrients uptake of wheat (Triticum durum cv. Salihli) under conditions of salinity. Asian J. Crop Sci. 2009, 1, 87-95. [CrossRef]

32. Gulser, F.; Sonmez, F.; Boysan, S. Effects of calcium nitrate and humic acid on pepper seedling growth under saline condition. J. Environ. Biol. 2010, 31, 873-876.

33. Turan, M.A.; Asik, B.B.; Katkat, A.V.; Celik, H. The effects of soil-applied humic substances to the dry weight and mineral nutrient uptake of maize plants under soil-salinity conditions. Not. Bot. Horti Agrobot. Cluj-Napoca 2011, 39, 171-177.

34. Aydin, A.; Kant, C.; Turan, M. Humic acid application alleviates salinity stress of bean (Phaseolus vulgaris L.) plants, decreasing membrane leakage. Afr. J. Agric. Res. 2012, 7, 1073-1086. [CrossRef]

35. Sadiq, S.A.; Baloch, D.M.; Ahmed, N. Hidayatullah Role of coal-derived humic acid in the availability of nutrients and growth of sunflower under calcareous soil. J. Anim. Plant Sci. 2014, 24, 1737-1742.

36. Schiavon, M.; Pizzeghello, D.; Muscolo, A.; Vaccaro, S.; Francioso, O.; Nardi, S. High molecular size humic substances enhance phenylpropanoid metabolism in maize (Zea mays L.). J. Chem. Ecol. 2010, 36, 662-669. [CrossRef] [PubMed]

37. Susic, M. Replenishing humic acids in agricultural soils. Agronomy 2016, in press. [CrossRef]

38. Alva, A.K.; Obreza, J.A. By-product iron-humate increases tree growth and fruit production of orange and grapefruit. Hortic. Sci. 1998, 33, 71-74.

39. USDA/National Institute of Food and Agriculture. Are Humates Good Soil Amendments? Available online: http: //articles.extension.org/pages/43098/are-humates-good-soil-amendments (accessed on 5 September 2016).

40. Liu, C.; Cooper, R.J. Humic acid application does not improve salt tolerance of hydroponically grown creeping bentgrass. J. Am. Soc. Hortic. Sci. 2002, 127, 219-223.

41. Leventoglu, H.; Erdal, I. Effect of high humic substance levels on growth and nutrient concentration of corn under calcareous conditions. J. Plant Nutr. 2014, 37, 2074-2084. [CrossRef]

42. Van Tonder, J.T. Effect of Potassium Humate on Soil Properties and Growth of Wheat. Master's Thesis, University of the Free State, Bloemfontein, South Africa, 2008.

43. Asli, S.; Neumann, P.M. Rhizosphere humic acid interacts with root cell walls to reduce hydraulic conductivity and plant development. Plant Soil 2010, 336, 313-322. [CrossRef]

44. Little, K.R.; Rose, M.T.; Jackson, W.R.; Cavagnaro, T.R.; Patti, A.F. Do lignite-derived organic amendments improve early-stage pasture growth and key soil biological and physicochemical properties? Crop Pasture Sci. 2014, 65, 899-910. [CrossRef]

45. Susic, M. Humic Acid: A History of Humic Acid Research. Available online: http://www.humicacid. wordpress.com/a-history-of-humic-acid-research/ (accessed on 6 June 2016).

46. Edmeades, D. The Organic Movement: New Products, Old Story, Same Nonsense. Available online: http: //www.agknowledge.co.nz/uploads/fert-review/Fertiliser-Review-Issue-25.pdf (accessed on 14 October 2016).

47. Fataftah, A.K.; Walia, D.S.; Gains, B.; Kotob, S.I. A comparative evaluation of known liquid humic acid analysis methods. In Humic Substances-Structures, Models and Functions; Ghabbour, E.A., Davies, G., Eds.; The Royal Society of Chemistry: Cambridge, UK, 2001.

48. Duval, J.R.; Dainello, F.J.; Haby, V.A.; Earhart, D.R. Evaluating leonardite as a crop growth enhancer for turnip and mustard greens. Hortic. Technol. 1998, 8, 564-567.

49. Feibert, E.B.; Shock, C.C.; Saunders, L.B. Nonconventional additives leave onion yield and quality unchanged. Hortic. Sci. 2003, 38, 381-386.

50. Chen, Y.; de Nobili, M.; Aviad, T. Stimulatory effects of humic substances on plant growth. In Soil Organic Matter in Sustainable Agriculture; CRC Press: London, UK, 2004.

51. Hartz, T.K. Humic substances generally ineffective in improving vegetable crop nutrient uptake or productivity. Hortic. Sci. 2010, 45, 906-910.

52. Chen, Y.; Aviad, T. Effects of humic substances on plant growth. In Humic Substances in Soil and Crop Sciences: Selected Readings; American Society of Agronomy and Soil Science Society of America: Madison, WI, USA, 1990; pp. 161-186.

53. Little, K.R. Commercial Lignite Coal-Derived Amendments for Improved Pasture Growth and Soil Health. Ph.D. Thesis, Monash University, Melbourne, VIC, Australia, 2015.

54. Annaeva, G.; Tekaev, A.; Namatov, B. Use of Tuarkyr brown coals as fertilizers. Probl. Desert Dev. 1987, 86-88. 
55. Rose, J. Chaff Rescues Saline Soil. Available online: http://www.stockjournal.com.au/story/3572411/chaffrescues-saline-soil/ (accessed on 27 September 2016).

56. Helal, A.A.; Murad, G.A.; Helal, A.A. Characterization of different humic materials by various analytical techniques. Arab. J. Chem. 2011, 4, 51-54. [CrossRef]

57. Xudan, X. The effect of foliar application of fulvic acid on water use, nutrient uptake and wheat yield. Aust. J. Agric. Res. 1986, 37, 343-350. [CrossRef]

58. Galeev, R.R. Application of sodium humate to potatoes. Kartofel' I Ovoshchi 1990, 2, 12-13.

59. Hassanpanah, D.; Gurbanov, E.; Gadimov, A.; Shahriari, R. Determination of yield stability in advanced potato cultivars as affected by water deficit and potassium humate in Ardabil region, Iran. Pak. J. Biol. Sci. 2008, 11, 1354-1359. [CrossRef] [PubMed]

(C) 2016 by the authors; licensee MDPI, Basel, Switzerland. This article is an open access article distributed under the terms and conditions of the Creative Commons Attribution (CC-BY) license (http://creativecommons.org/licenses/by/4.0/). 